\title{
Étienne De La Boétie Üzerine Bir İnceleme ${ }^{1}$
}

\author{
A Study on Étrenne De La Boétıe
}

Gökhan ÇELEN²

Geliş tarihi: 10.05.2018, Kabul tarihi: 31.08.2018, Basım tarihi: 30.09.2018

\section{Özet}

Modern devletin örgütlenme biçimi uzun bir süreç sonucunda şekillenmiştir. Bu sürecin başlangıcını feodal dönemin sonlarına kadar dayandıran görüşler olmasına karşıı asıl şeklini XVI. ve XVII. yüzyıllarda aldığı söylenebilir. Rönesans ve Reform hareketleri sonrasında Kilise'nin otoritesinin zayıflaması, feodal sistemin çözülmeye başlaması ve yaşanan teknolojik gelişmeler modern devletin oluşumuna giden süreçteki önemli faktörlerdir. İncelemesi yapılan düşünür Étienne de La Boétie de bu siyasi iklimde yaşamış, dönemin toplumsal ve siyasal sorunlarından etkilenerek siyaset felsefesi literatürüne ölümsüz bir eser bırakmıştır. Bir Rönesans insanı olan La Boétie, insan doğasının özgür ve eşit olduğunu ancak, insanların gönüllü olarak iktidara kul olduklarını söylemiştir. Bu çalışmanın amacı La Boétie'nin insanın doğası ve insanların neden iktidara boyun eğdiklerini tartıştığı Gönüllü Kulluk Üz̨erine Söylev eserinin çözümlenmesidir. Bu bağlamda, La Boétie’nin eserinin çözümlenmesi N. Machiavelli ve toplum sözleşmecilerinin görüşleri ile genel olarak karşılaştırılarak La Boétie'nin görüşleri incelenmiştir. Ayrıca eserde iktidarın benimsetilmesini sağlayan araçlar sunulurken kullanılan yöntemin Antonio Gramsci'nin "hegemonya" kavramıyla olan ilişkisi sorgulanmıştır. Modern devletin kuruluşunu çözümleyen La Boétie'nin yaşadığı dönemdeki siyasi iklim, eserin ortaya çıkışı, evrensel mesajları ve eserde sunulan tezler tartışılmıştır. Çalışmada karşılaştırmalı analiz ve yorumsamacılık yöntemleri kullanılmıştır.

Anahtar Kelimeler: Eşitlik, gönüllü kulluk, insan doğası, özgürlük, tiran.

\begin{abstract}
The process of organizing the modern state took place over a long period of time. This is the beginning of the process until end of feudal era, although the principal opinions which retained the shape of the XVI. and XVII. centuries can be said to have received. The weakening of the authority of the Church after the Renaissance and Reform movements, the beginning of the dissolution of the feudal system and the technological developments that are experienced are important factors in the process of the formation of the modern state. Étienne de La Boétie, who studied the subject, lived in this political climate and was influenced by the social and political problems of the time and left an immortal work in the literary

\footnotetext{
${ }^{1}$ Bu çalışma 29 Kasım-1 Aralık tarihleri arasında gerçekleştirilen 15. Ulusal Sosyal Bilimler Kongresi'nde sözlü bildiri olarak sunulmuştur.

2 Akdeniz Üniversitesi, İ̈BF, SBKY Bölümü, Siyaset ve Sosyal Bilimler ABD, Arş. Grv., Doktora öğrencisi, https://orcid.org/0000-0002-4853-228X

gokhancelen@outlook.com
} 
texts of political philosophy. La Boétie, a Renaissance man, said that human nature is free and equal but people are being servants of power voluntarily. The intent of the work is to resolve the work of La Boétie on the subject of Discourse on Voluntary Servitude, which discusses the nature of man and why mankind obeys power. In this context, the analysis of La Boétie's work was generally compared with the views of N. Machiavelli and social contract theorists, and La Boétie's messages were revealed. In addition, the relation between the method used by A. Gramsci as the hegemony and the method used when giving the tools for the adoption of power was questioned. The political climate, the emergence of the work, universal messages and the theses presented in the work were discussed during the period of La Boétie's analysis of the constitute of the modern state. Comparative analysis and interpretation methods were used in the study.

Keywords: Equality, voluntary servitude, nature of man, freedom, tyranne.

\section{Giriş}

Siyasal iktidar mücadeleleri insanların oluşturduğu ilk toplumlara dek uzanmaktadır. İktidar mücadelelerinde en önemli noktalardan biri ise, iktidarın meşruiyet kaynağına ilişkin süregelen tartışmalardır. İktidarı ele geçirmiş olmak, iktidarın devamlılı̆̆ını sağlayabilmek için yeterli değildir. Hükmetmenin temeline ve devamlılı̆̆ına ilişkin erk sahiplerinin sunduğu bütün savlar meşruiyet kazanma çabasına yöneliktir. Roma İmparatorluğu'nun parçalanması sonrasında Avrupa'da ortaya çıkan feodal sistemin başat aktörlerinden biri olan kilise ${ }^{3}$, iktidarın temelinin Tanrı'dan geldiğini vurgulayarak dünyevi iktidarların hükmetme erkini ancak kilisenin bu durumu onamasıyla birlikte kullanabileceğini iddia etmiştir. XIV. yüzyıl ile birlikte kilise öne sürdüğü çifte k1lıçlar kuramında (plenitudo potestatist) yönetme erkini temsil eden kıllçların her ikisinin de kendisine ait olduğunu söyleyerek hem ruhani hem de dünyevi iktidar hakkının kendisine ait olduğunu belirtmiştir. Ancak bu iddiaya karşı savlar geliştirilecek ve iddia edilenin zittı bir durum ortaya çıkacaktır (Ağaoğulları, 2011: 263-272). Dante, De Monarchia (Monarşi Üzerine) adlı eserinde dünyevi iktidarın oluşumunun doğal bir zorunluluk olduğunu ve ortaya çıkışının kiliseden önce ve bağımsız olarak meydana geldiğini söyleyerek dünyevi iktidarın Tanrı'nın isteğiyle ortaya çıktığını savunmuştur. Bu savlarıyla devleti kiliseden bağımsızlaştırmaya çalışmıştır (Ağaoğulları, 2008: 41-48). Dante ile başlayan, dünyevi iktidarı kendi ülkesinde bağımsız ve egemen kılma fikirleri, çağdaşı Ockhamlı William, Podovalı Marsilius, Martin Luther gibi birçok düşünürce de desteklenmiştir. Avrupa siyasi ve toplumsal sistemini kökten

\footnotetext{
${ }^{3}$ Kilise burada merkezi Vatikan'da bulunan Katolik Kilisesi kurumunu ifade etmektedir.

${ }^{4}$ Bütün iktidarların (dünyevi ve ruhani) tek elde toplandığı savıdır. Ortaçağ döneminde kilise, bu savı ortaya atıp dünyevi iktidarın da (imparator ve kralın iktidarı) kiliseye ait olduğunu ileri sürmüştür. (Ayrıntılı bilgi için bkz: Ağaoğulları, 2011: 248).
} 
değiştirecek olan Rönesans ve Reform hareketleri ile kilisenin maddi dünya üzerindeki etkisi ortadan kalkacak ve bazı monarşilerde kilise devlete bağlı bir kurum haline getirilecektir.

Kilisenin etkinliğinin zayıflaması, gelişen teknolojik ve toplumsal koşullar feodalitenin çözülmesine önayak olurken, monarşiler merkezi otoritelerini güçlendirmek için çalışmaya başlamışlardır. Rönesans'in en dikkat çekici düşünürlerinden olan Niccolo Machiavelli özgürlüğü ulusal bütünlük olarak algılamış ve bu amaca ulaşmak için yöneticiye ögüüler içeren Il Principe (Prens) adlı eseri kaleme almıştır. Düşünürün amacı güçlü bir prens aracıllı̆ıyla İtalya'daki parçalı prensliklerin birleştirilmesi ve merkezi otoritenin sağlanmasıdır. Çalışmamız açısından eserin önemi Machiavelli'nin insan doğasına bakış açısı ve bu bakış açısı üzerinden açıklanan iktidarın zorunluluğu fikridir. Tipk1 Machiavelli gibi yüzyıllar boyunca kuramcılar ve düşünürler, iktidarın kaynağı ve hükmetme mücadelelerinde hangi unsurların etkin olacağını tartışırken Étienne de La Boétie, insanların iktidara neden itaat ettiğini sorgulamıştır. La Boétie, XVI. yüzyılda kaleme aldığ1 Gönülliü Kulluk Üzerine Söylev kitabı ile iktidarın meşruiyetini sorgulamış ve insanların neden iktidarlara kulluk ettiklerini ve hatta bu kulluğu neden gönüllü olarak sürdürdüklerine odaklanmıştır.

Çalışmada öncelikle La Boétie’nin yaşamı ve çalışmamıza konu olan eserinin tarihçesi incelenecektir. Bu inceleme sonrasında La Boétie'nin, Machiavelli ve toplum sözleşmecilerinin insan doğasına bakış açıları genel olarak karşılaştırılarak iktidarın ortaya çıkışı ve insanların iktidarla olan ilişkileri üzerine düşünürlerin fikirleri ortaya konmaya çalışlacaktır. La Boétie'nin insan doğasına bakış açısı ve iktidarın ortaya çıkışına dair fikirlerinin incelemesi sonrasında irdelenecek diğer bir konu ise Söylev'de sunulan fikirlerin anarşizmle bağlantısı olup olmadığıdır. Bu inceleme La Boétie'nin anarşist olup olmadığı konusundaki tartışmaya katkı sağlayacaktır. La Boétie ile ilgili dikkat çekici bir diğer durum ise, Antonio Gramsci'nin "hegemonya" kavramını XVI. yüzyıl Fransa'sında çözümlemiş olmasıdır. İktidarın devamlılı̆ını ve meşruiyetini sağlama noktasında başvurduğu yöntemleri aktarırken sunulan çözümlemenin Gramsci tarafindan tanımlanan hegemonya kavramı ile olan ilişkisini de incelemek gerekmektedir. Çalışma Söylev'de sunulan fikirlerin eleştirel çözümlemesi yapılarak sonlandırılacaktır. Çalışmada karşılaştırmalı analiz ve yorumsamacılık yöntemleri kullanılmıştır. Karşılaştırmalı analiz yöntemi La Boétie'nin çözümlemelerini ortaya koymak ve dikkati bu fikirlere yoğunlaştırmak için seçilmiştir.

\section{1. Étienne de La Boétie'nin Yaşamı ve Dönemi}

XVI. yüzyll düşünürlerinden olan La Boétie 1 Kasım 1530 yllında, Fransa'nın güneybatısındaki Perigord bölgesinin Sarlat kentinde doğmuştur. Ailesi zengin ve soylulaştırılmış burjuva sınıfındandır. Bu sınıf özellikle XV. 
ve XVI. yüzyllda monarşinin en önemli destekçilerinden biridir. Zenginliklerini ve konumlarını kurumsallaşan ulusal monarşiye bağlamışlardır. Bu desteğin karşılığ olarak da monarşi, önemli devlet görevlerini bu sınıf içerisinden kişilere teslim etmiştir (Ağaoğulları, 2008: 276).

Fransa, erken modern dönemden 1789'a kadar baskın bir aristokrasi ve soyluluk unvanı satın almış seçkinler grubunun eşliğindeki krallar ve prensler tarafından yönetilmekteydi. ${ }^{5}$ Fransa'nın gelişmeye başlayan kentleri olmasına karşın ağırlıklı olarak tarıma dayalı kırsal bir görünümü vardı (Price, 2012: 31). İktidar toprak sahipliğine ve toplumsal konuma bağlıydı. Dolayısıyla zenginleşen burjuvazi bir anlamda soyluluk satın alarak toplumdaki statüsünü yükseltmekteydi (Moore, 2012: 73-74).

XVI. yüzyllda La Boétie’nin doğduğu Fransa'nın güney bölgesinde ticaretin tarıma oranla daha etkili olması ticaret burjuvazisinin yükselişini sağlamış, bu durumun sonucunda feodal sistemin bölgede çözülmesi hızlanmış ve Kilise'nin etkisi silikleşmişti. Feodal yapıların hızlı bir şekilde çözülmesi, değişen toplumsal değerler ve ekonomik koşullar bu bölgedeki soyluların konumunu ise olumsuz yönde etkilemişti.

La Boétie, ailesinin etkisi ile Orleans Üniversitesi’nde hukuk eğitimi almıstır. Aldığı eğitimin düşünceleri ve eserleri üzerinde etkili olduğunu düşünülmektedir. XVI. yüzyılda hukuk fakültelerinde hümanizm ve Reform hareketlerinin geliştiği görülmektedir. Protestan Parti'nin önde gelen liderlerinden olan Anne du Bourg, Orleans Üniversitesinde La Boétie'nin hocalığını yapmıştır. Düşünürün fikirlerinde hocasının demokrat görüşlerinin de etkili olduğu düşünülmektedir.

Orleans Üniversitesinden 1553 yllinda mezun olan La Boétie, 1554 yilında Kral II. Henry'nin onayı ile Bordeaux Parlamentosunda ${ }^{6}$ danışmanlık görevine başlamıştır. Uzun yıllar dostluk kuracağı ve eserini dünyaya tanıtan Montaigne ile bu görevi sırasında tanışmıştır. La Boétie'nin bu göreve gelişi yukarıda bahsedilen burjuva ve monarşi arasındaki ilişkiyi kanıtlar niteliktedir.

XVI. yüzyılda Fransa'nın en önemli problemlerden biri din çatışmalarıydı. Bu yüzyılda Katolikler ve Protestanlar arasında ciddi sorunlar yaşanmaktaydı. Monarşi, bir yandan krallığı zayıflatan bu çatışmalara çözüm bulmaya çalışırken, bir yandan da kiliseye karşı gücünü pekiştirme

\footnotetext{
${ }^{5}$ Fransa erken modern dönemden 1789'a kadar klasik feodal yapıdan mutlak monarşiye dönüşen bir siyasal rejim değişikliği yaşamıştır. Burada üzerinde durmak istenilen husus yönetici elitlerdir.

${ }^{6} \mathrm{Bu}$ dönemde parlamento, yasama işlerine değil adalet ile ilgili işlere bakmaktadır. Amaçları monarşi adına adaleti sağlamak ve kanunların uygulanmasını sağlamaktır.
} 
çabasındaydı. Çatışmaların tarafı olan veya bu konuda fikir beyan eden Katolik Parti, Protestan Parti ve Politikler Partisi olmak üzere üç akım bulunmaktaydı. Üçüncü akım olan Politikler Partisi'nin görüşleri, monarşi tarafindan desteklenmekteydi. Politikler, Katolikliğin devlet dini olarak kalmasını Protestanların da dini özgürlüklerinin güvence altına alınması gerektiğini belirtiyorlar ve dönemin şartlarına uygun olarak kiliselerin mutlak bir biçimde monarşiye bağlanmasını savunuyorlardı. Ocak Fermanı Üzerine Inceleme adlı metin ile mezhep çatışması hakkında fikirlerini dile getiren La Boétie, bu çatışmaların ülkede iki ayrı devlet görüntüsü ortaya çıkardığını ve bunu çözebilecek merciinin de kiliselerin koruyucusu olan monarşi olduğunu savunmuştur (Ağaoğulları, 2008: 278-279). Murray Rothbard'1n giriş bölümü yazdığ1 Gönüllü Kulluk Üzerine Söylev eserinin Harry Kurz tarafından yapılan çevirisinde Rothbard, La Boétie'yi Fransız modern felsefesinin kurucusu olarak değerlendirmiştir (Boétie, 2008: 7). La Boétie 1563 y1lında çok genç yaşta salgın hastalık nedeniyle hayatını kaybetmiştir. Ardında bıraktığı Gönüllü Kulluk Üzerine Söylev adlı eserinin ortaya çıkış süreci ise eser hakkında günümüzde halen fikir ayrılıklarına sebep olan bir şekilde olmuştur.

\section{Söylev'in Tarihçesi}

Gönüllü Kulluk Üzerine Söylev eserinin ne zaman yazıldığına dair kesin bilgiler olmamasina karşın Montaigne düşünürün Söylev’i 16-18 yaşları arasında yazdığını belirtir. Fakat eser üzerinde yapılan incelemeler, eserde verilen bazı örneklerin ancak 1548 y1lından sonra yayınlanmış eserlerden alınabileceğini, dolayısıyla Söylev'in 1548 yılından sonra yazılmış olabileceği gibi bu tarih itibariyle üzerinde güncelleme yapılmış olma ihtimalini de göstermektedir. Ayrıca La Boétie'nin 1549 yılında yaşanan ve yönetim tarafından şiddetle bastırılan Gabelle Ayaklanmasından etkilenmiş olabileceği de ileri sürülen fikirler arasındadır ${ }^{7}$. Eserde doğrudan bahsedilmese de, bu ayaklanmanın köylülerin hoşnutsuzluk protestosundan dolay1 ortaya çıkmadığını, köylülerin tepkisini çeken şeyin iktidarın kendisi olduğunu belirterek La Boétie'nin modern devlet aygıtını keşfettiği ve bu temel üzerinden eleştirilerini yoğunlaştırdığı ileri sürülmektedir. La Boétie'nin üniversite hocası Anne du Bourg'un görüşlerinden etkilenme olasıllı̆1 da güçlü görünmektedir (Boétie, 2008: 9; Ağaoğullar1, 2008: 279-280).

La Boétie Antik Yunan ve Roma dönemlerinden eserlerin çevirilerini yapmıştır. 1570 yılında Montaigne bu çalışmaları yayımlamasına rağmen, orijinal metni elinde bulunan Söylev'i yayımlamamıştır. Monaigne'nin

7 La Boétie'nin yakın dostu Montaigne de Gabelle ayaklanmasına şahit olmuş ve bu ayaklanmadan ciddi şekilde etkilenmiştir. La Boétie Montaigne'e yazdığı bir mektupta bu durumun vahametinden bahsetmiştir. Bu ayaklanma her iki düşünürün de yaşamlarında ciddi izler bırakmışır (Zweig, 2012: 22-24). 
dostunun Monarkomak ${ }^{8}$ olarak yaftalanmaması için Söylev'i yayımlatmadı̆̆1 düşünülmektedir. Montaigne eseri yayımlatmasa da sebebi bilinmeyen bir şekilde eser buguenotlarca ${ }^{9}$ ele geçirilmiş ve kendi yayınlarında önce yazar ismi verilmeden bazı parçaları, 1576 yılında ise düşünürün adı verilerek tam metin halinde Contr (Bir'e Karşı) adıyla yayımlatılmıştır (Göze, 2016: 249). Bu gelişmeler sonrası monarkomak olarak adlandırılan La Boétie'yi savunmak için Montaigne eserin tam metnini yayımlatır ve eserin bir "gençlik günahı" (Ağaoğulları, 2008: 282) olduğunu ifade eder. Monarkomakların eserleri ile kıyaslandığında La Boétie'nin monarkomak gruba dahil olmadığ1 görülmektedir. La Boétie Antik Yunan'dan örnekler kullanarak halkın iktidara nasıl boyun eğdiğine ve iktidarında bu egemenliği nasıl sürdürdügüne odaklanmasına karşın, monarkomaklar eserlerinde belirli Fransız kurumlarına odaklanarak halkın baskı altında bulunan bölümü için özgürlük taleplerinde bulunmuşlardır (Boétie, 2008: 10).

Eserle ilgili diğer bir iddia, Söylev'in Montaigne'nin kendisine ait olduğu ya da kendisi tarafindan sonradan değiştirildiği fakat La Boétie'nin adıyla gençlik günahı olarak yayımladığıdır (Kurz, 1946; Pieters \& Roose, 2006: 8182). Schaefer, bu duruma kanıt olarak Söylev'de Ronsard'in Franciade eserinden bahsedildiğini, fakat bu eserin 1572 yllına kadar ortaya çıkmamış olduğunu göstermektedir (Schaefer, 2013: 596). Arthur Armaingaud da, Söylev'in Montaigne'ye ait olduğunu, yönetimin baskısından kaçınmak için La Boétie'nin ismini kullandığını iddia etmiş ve kanıt olarak ise Söylev'de III. Henry dönemine ait göndermeler bulunduğunu La Boétie'nin ise III. Henry döneminden önce öldügünü sunmuştur. Montaigne'nin Söylev'in masumiyetini eseri La Boétie'ye atfederek sağladığını iddia etmiştir. Bernadette Gadomski ise Söylev ve Protestan geleneği arasındaki ilişkiyi La Boétie, penseur masque (Paris, 2017) isimli kitabında tekrar tartışmaya açmıştır. Söylev'de savunulan tezlerle Calvinci doktrinler arasındaki yakın bağlantıyı göstermeye çalışış ve Montaigne'nin değil La Boétie'nin kendisinin Söylev aracilığılla Huguenotarın tiranın zorbalıklarına, Katoliklere ve hükümdara karşı duruşlarını desteklediğini iddia etmişsir. Garcia-Alonso ise, La Boétie'nin Monarkomakların lideri olmadığını ve eserin Reformist doktrine karşı yazılmış parlamentarizmin savunusu olarak okunabileceğini iddia etmiştir (García-Alonso, 2013: 318-319).

La Boétie'nin Söylev'i 1789 Fransız İhtilaline giden süreçte yeniden güncellik kazanmıştır. Fransız ihtilalinde insanları politik olarak mobilize etmek için insan doğasının özgürlüğü temelinde yararlanılan eser, Napoleon Darbesi ile birlikte tiranlığa karşı yönü ile önem kazanmıştır.

\footnotetext{
8 Ayrıntılı bilgi için bkz. Ağaoğulları (2008: 309), Price (2012: 77-79).

${ }^{9}$ Fransız Calvincileri.
} 
20. yüzyılda ilk olarak Almanya'da Nazi iktidarına karşı gündeme getirilen Söylev, 1970'li yıllarda ise Fransa'da iktidarın baskıcı ve otoriter özü üzerine çalışan entelektüellerce yeniden okunmuştur. Söylev özgürlüğün kısıtlandığ1 her dönemde yeniden güncellik kazanmış ve despotizmden kurtulmanın yöntemlerinden birisi olan sivil itaatsizliği erken bir dönemde örnekleyen bir eser olarak görülmüştür (Kurz, 1949: 128).

İktidara gönüllü olarak boğun eğmeyi insan doğası ve modern devlet aygıtının araçları ile açıklayan eser, kendisinden yaklaşık iki yüzyıl sonra ortaya çıkacak olan toplum sözleşmecilerine de düşünceleriyle esin kaynağ1 olmuştur. La Boétie Söylev'de iktidarın özünün ne olduğuna odaklanmış ve iktidarın halkı gönüllü kulluğa nasıl ikna ettiğini incelemiştir.

\section{Machiavelli, La Boétie ve Toplum Sözleşmecilerinde İnsan Doğası Tartışması}

Siyaset felsefesinde insan doğasına yönelik yaklaşımlar düşünürlerin fikir sistematikleri bakımından büyük önem taşımaktadır. Machiavelli'nin ve La Boétie'nin insan doğasına bakış açlarını incelemek siyaset felsefesi yazınında insanın doğasına dair sunulan iki temel karşıt görüşü ortaya koymamızı sağlayacaktır. Bu iki düşünürün insan doğasına bakış açıları kendilerinden sonra gelen düşünürlerce takip edilecek ve oluşturulan düşünce sistemleri bu temellere dayandır1lacaktır.

Machiavelli'nin insana ve onun doğasına bakış açısı olumsuzdur. İnsanların özünde kötülük bulunduğunu defalarca dile getiren düşünür, insanların genellikle "nankör, kaypak, iki yüzlü, tehlikeler karşısında ürkek ve kazanç düşkünü yaratıklar” (Ağaoğulları, 2008: 180) olduğunu dile getirir. İnsanlar1 sahiplenme (mülkiyet) duygusunun yönlendirdiğini ve bu duygunun insanların her şeyi arzulayıp ele geçirmeye çalşsarak sürekli yeni arayışlar peşinde koşan ve birbirlerini kıskanan kişilik biçimleri ortaya çıkardığını söyler. İnsanın bu özelliği onu elindekini arttırarak korumaya yönlendirir. Bu da her bir insanın daha fazla güç ve iktidar peşinde olmasıdır. Bu sebeple insanlar sürekli iktidar mücadelesindedirler. Bu durum insanın doğasından kaynaklanmaktadır ve bundan sakınmak mümkün değildir. Doğasında kötülük olan insan karşısındaki diğer insanları kendisine rakip ve engel olarak görür. Dolayısıyla herkes birbiri için kötüdür. Machiavelli, iktidarı ele geçirilecek bir olgu olarak algıladığından dolayı herhangi birinin iktidarının artması diğerlerinin iktidarının azalması anlamına gelmektedir. İnsanların iktidarlarını ya da çıkarlarını kaybetme kuşkusu içinde olmalarından dolayı bu davranış1 sergilediklerini söyler (Ağaoğulları, 2008: 182-183).

Machiavelli insan doğasına dair yaptığ çözümlemeyi insanların sabit özellikleri olarak değerlendirmiştir. Geçmişin açıklanması ve geleceğin inşa edilmesi bu çözümleme sonucunda kestirilebilir olmaktadır. İnsanın doğası siyasal alana da aynı şekilde yansıdığından dolayı insan doğasına bakış açısı 
yöneticilerin yönetilenlere karşı tavırlarını belirlemektedir. Yöneticilerin hangi eylemler aracıllŏgyla yönetilenleri idare edebilecekleri, yönetilenlerin hangi eylemlere rıza gösterip yöneticiyi kabullendikleri ve tam tersi durumlar tarih incelenerek ve insan doğası göz önüne alınarak belirlenebilecektir. Machiavelli var olan gerçeklikten hareket ederek iktidarın elde tutulma yöntemlerini insanların iktidar arzuları üzerinden tanımlamıştır (Gülenç, 2014; Machiavelli, 2015). Çünkü Machiavelli'ye göre iktidarı elde tutma ve ele geçirme arzusu için verilen mücadeleler zorunlu olgulardır. Bu sebeple bütün iktidarların sahip olması gereken başlıca unsurlar iyi yasalar ve ordular olmalidır.

Machiavelli özgürlük konusuna bireyin özgürlügünden çok iktidarın ya da devletin özgürlüğü üzerinden değinmiştir. Özgürlüğü hem negatif hem de pozitif şekilde tanımlamaktadır. Machiavelli'ye göre negatif anlamda özgürlük devletin hem iç hem de dış işlerinde bağımlı olmama halidir. İktidar bağımsız hareket edebiliyorsa, yönetilenler de ortak amaç ve çıkarlar etrafinda bir araya gelebilirler. Yönetim içte ve dişta bağımsız olduğunda pozitif anlamda özgürlük ortaya çıkmaktadır. Machiavelli bu durumu toplumun özyönetimi düşüncesiyle bağlantılı olarak düşünmektedir. Birey için özgürlük kendi yarar ve çıkarları için toplumsal kurumlara riayet etmek veya toplumun otoritesini kabullenip yaşamak anlamına gelmektedir (Gülenç, 2014). Machiavelli için bireyin özgürlüğü ön planda değildir. Özgürlük konusunda onun için odak nokta devletin özgür olması ve toplumun iradesiyle refah düzeyinin oluşturulmasıdır.

La Boétie, Machiavelli'ye karşıt bir düşünceyle, insan doğasının özgür olduğunu ve "özgürlügümüzü koruma duygusuyla doğduğumuzu" (Boétie, 2014: 28) belirtir. Fakat zamanla insan bu özgürlüğünü yitirmiş ve kulluğa mahkûm olmuştur. İnsan doğadan ve doğasından koptuğu için kulluk durumuna düşmüştür. Felsefi natüralizm biçiminde beliren doğa anlayışında La Boétie doğayı “Tanrı'nın vekili ve insanların yöneticisi” (Boétie, 2014: 27) olarak tanımlamıştır. Doğa, insanı akıl ile donatmış benzer ve eşit olarak yaratmıştır. Özgürlügün doğal olması da insanların birbirini “yoldaş olarak ya da daha doğrusu kardeş olarak" (Boétie, 2014: 27) görebilmelerinden kaynaklanmaktadır. İnsanlar konuşma yeteneği sayesinde birbirlerini tanırlar ve uzlaşıya varırlar. Toplumda farklılıklar vardır fakat toplumsal ilişkilerde karşılıklı iletişim sayesinde anlaşma sağlanır ve bu farklılıklar yaşama yansımaz. Çünkü eşit olarak yaratılmış insan, bir diğerini kendisinin aynası olarak görür ve bu sayede kendini de tanıyabilir. La Boétie insan doğasının özgür ve insanların eşit olduğunu sıklıkla vurgulayarak açıcça eşit yurttaşlık tutkusunu belirtmiştir (Sparling, 2013: 490).

Machiavelli insan doğasını bencillik ve kötülük üzerinden çözümleyerek iktidarın uygulaması gereken yolları sunmaya çalışırken, La Boétie doğaya ve akla uygun olarak hükmeden-hükmedilen ayrışmasının olmadığı ve insanların 
siyasal iktidar tarafindan kulluklaştırılmadığı toplumu idealize etmiştir. Sözleşmeci kuramcılar La Boétie'nin kurduğu bu toplumu doğa durumu olarak adlandırmışlardır.

Ancak doğa durumu bozulmuş, tiranların iktidarı altında insanlar hem özgürlüğünü hem de özgürlüğü koruma duygularını yitirmişlerdir. La Boétie, bu durumun sorumlusunun tiran değil ona itaat eden insanlar olduğunu söyler. İnsanların nasıl olup da tek bir kişinin iktidarı altında kulluklaştığını anlamaya çalışırken "iki kişi tek kişiden çekinebilir; on kişinin de çekinmesi olasıdır. Fakat bin kişi, bir milyon kişi, bin kent, eğer kendilerini bir kişiye karşı koruyamıorlarsa bu korkaklık değildir" (Boétie, 2014: 21) yorumunu yapmıştır. Korkaklığın, alçaklığın ve tüm erdemsizliklerin bir sinırı olduğunu, nasıl yiğitlik tek başına bir kaleye saldırmak değilse korkaklı̆̆ın da böyle bir sınırının olmadığını söyler. Demek ki tirana boyun eğen halk sadece özgürlüğünü yitirmemiştir, özgürlüğünü koruma arzusunu da yitirmiştir. Köleliğin tek sorumlusu halktır. Siyasal iktidarın varlığını sağlayan etken ise halkın ona itaat etme arzusudur. Çünkü özgürlüğe kavuşmak için "tirana karş1 koymak, onunla savaşmak gerekmez bile" (Boétie, 2014: 23), insanlar kulluk etmemeye karar verdikleri an tiranlık ${ }^{10}$ başka bir eylem gerektirmeksizin yıkılacaktır.

Tiranı tiran yapan halkın kendisinden ona verdiği organlardır. Modern devlet aygıtının ilk nüvelerinin görülmeye başladığı dönemde devletin halka yansımasinı ve halkın tiranı yaratmasını "eğer siz vermediyseniz, sizi gözetlediği bu kadar gözü nereden buldu? Sizden almadiysa, nasıl oluyor da sizleri dövdügü bu kadar çok eli olabiliyor? (...) Sizin tarafınızdan verilmiş olmasa üzerinizde nasıl iktidar olabilir?" sözleriyle açıklar.

Siyasal iktidarın kökenini halkın kölelik istencine bağlayan La Boétie, kendisinden önceki felsefi tartışmalardan hem laiklik anlayışı ile (iktidarın kaynağını 'Tanrı'ya bağlamayarak) hem de siyasal iktidarın kaynağı konusunda devrim niteliğinde fikirler sunarak farklılaşmıştır (Göze, 1969: 248-249). Aristoteles'in monark/kral-tiran ayrımına girmemiş, tüm yetkilerin bir kişide toplandığ1 rejimi tiranlık olarak tanımlamış ve kurumsallaşmış otoritenin tüm biçimlerini reddetmiştir (Keohane, 1977: 127; Sparling, 2013: 489). Schaefer, bu ayrımın yapılmamasını eserin başarısızlığı olarak yorumlasa da (2013: 596)

\footnotetext{
10 Tiran kelimesinin Asya kökenli olduğu ve Yunan diline Lydia dilinden geçtiği tahmin edilmektedir. Kelimenin orijinal anlamı efendi ya da kraldır. Ancak Yunanlılar bu kelimeyi Doğulu despotları tanımlamak için kullanmışlar ve kelime bu şekilde aşağılayıcı bir anlam değişikliğine uğramıştır. Yunanlı için tiranın kraldan farkı, iktidarı yasal ve geleneksel olmayan şekilde ele geçirmesi, keyfi bir yönetim sürmesidir (Ağaoğulları, 2006: 36). Aristoteles de tiran kelimesini "devlet dediğimiz siyasal birlik üstünde despotça yürütülen monarşi biçimi”" şeklinde tanımlamıştır (2006: 81).
} 
eserde net bir şekilde yönetim şekillerini birbirinden ayırt etmenin anlamsızlığ1 vurgulanmıştır.

La Boétie, iktidarın temelini halkın kulluk arzusuna bağlamış fakat, "boyunduruk altında doğup özgürlüğün gölgesini bile görmeyip köle olmanın ne kadar kötü bir şey olduğunu anlamayan insanların hoş görülmelerinin” (Boétie, 2014: 36) gerektiğini belirterek, gönüllü kulluğun tamamlanması ve sürdürülebilmesi için siyasal iktidarın etkinliklerine eğilmiştir. Eserin çelişki ve zayıflıklarından biri olan bu durum dikkat çekicidir. La Boétie, iktidarın ortaya çıkmasını önce halkın özgürlük istencini kaybetmesine bağlamış fakat, tiranı incelemeye geçtiğinde özgürlüğü yitiren kuşaklardan sonraki kuşakların özgürlügü hiç tanımadıklarını ileri sürerek, gönüllü kulluğun nedenlerini tiranın faaliyetlerine bağlamıştır.

Machiavelli ve La Boétie'nin insan doğası ve iktidarın meşruiyet kaynağ hakkındaki düşüncelerini inceledikten sonra, T. Hobbes, J. Locke ve J. J. Rouuseau'nun bu konulardaki düşüncelerine kısaca değinerek Machiavelli ve La Boétie'nin düşüncelerinin kendisinden sonra gelen düşünürleri nasıl etkilediğini değerlendirebiliriz.

Hobbes'un insan doğasına bakış açısı Machiavelli'yle benzeşmektedir. Hobbes insan doğası ve siyasete dair felsefi argümanlarını İngiliz devrimini anlamak ve açıklamak için kullanmıştır (Kulak, 2014). Hobbes insan doğasının özünde bencil olduğunu vurgular. Ona göre özgür irade yoktur. Maddenin sürekli hareketini kuramının çıkış noktası olarak belirleyen Hobbes, duyum, duygu ve düşünceleri neden-sonuç ilişkileri temelinde açıklamaya çalışır. Hobbes'e göre insan davranışının tamamını açıklayan fizyolojik ilke kendini korumadır. İnsanlar hazza yönelen ve kendilerine zararlı olan şeylerden kaçan bencil yaratıklardır. Bu düşüncelerle bencilliğin kökenini bilimsel açıdan açıkladığını savunan Hobbes, göreceliliğe yönelir ve evrensel ahlak kurallarının olmadığını söyler. İnsanların bencilliğinden dolayı ahlak kuralları kişilere göre değişir. Fizyolojik olarak insanın temel güdüsü kendini korumak olduğu için yaşamın korunması ve bu yolda gerçekleştirilen eylemler iyi, tersi durumlar ise kötüdür (Ağaoğulları, 2009: 186).

Hobbes, Leviathan adlı eserinde insanların doğuştan eşit olduğunu, bu eşitlikten güvensizliğin ortaya çıktığını ve güvensizliğin de savaşın sebebi olduğunu iletir. La Boétie'ye benzer bir şekilde insanın doğal olarak toplumsallık eğilimine sahip olmadığını, bu eğilimi sonradan kazandığını ileri sürer. Ancak La Boétie'nin aksine söylemini iktidarın zorunluluğu üzerinden sürdürecektir. Hobbes'un doğa durumu olarak tanımladığı devlet öncesi toplum ya da topluluk insan doğasının özelliklerini yansıtır. Dolayısıyla devlet olmadığında herkes herkese karşı savaş verir. Ancak merkezi iktidar ile birlikte insanlar doğal haklarını kullanabilir. Doğal hak insanın kendi hayatını korumak amacıyla en uygun kabul ettiği her şeyi yapma özgürlüğüdür. Hobbes özgürlüğü diş engellerin yokluğu olarak tanımlar 
(Hobbes, 2014: 209-213). Hobbes'a göre, doğal hak ve özgürlük ancak merkezi bir devlet aracılığıyla mümkün olacaktır.

İngiliz kuramc1 J. Locke da, Hobbes gibi, kuramını açıklamak için doğa durumu varsayımına başvurmuştur. Ancak, Locke, Hobbes'un tersine, doğa durumunda insanların eşit ve özgür ${ }^{11}$ olduğunu ileri sürer. Eşitsizlik insan ürünüdür ve yapaydır. Locke'nin insan doğasına dair düşüncelerini doğa durumunda çizdiği toplum modeli üzerinden çıkarabiliriz. Locke’a göre, doğa durumunda doğa yasası geçerlidir. Doğa yasas1 ${ }^{12}$ akıl temelinde tanımlanır ve evrenseldir. Doğa durumunda yaşayan insanlar akıl ölçütüne göre yaşamaktadır. Locke insan doğasına bu aşamada pozitif özellikler yükler. Ancak doğa durumunun bozulması sürecini açıklarken insan doğasına atfettiği pozitif özellikler yerini olumsuz özelliklere bırakır. Çelişkili olan bu durumun gerekçesi doğa durumunun bozulmasını mümkün kılmak içindir. Çünkü Locke’un kuramında iktidar oluştuğunda da bireyin özgürlüğü ve iktidarın meşruiyetini sağlamak için bireyin onayı şart koşulur. İnsan doğasının olumsuz özellikleri doğa durumunun bozulmasına neden olan cezalandırma hakkı üzerine verdiği bilgiler içerisinde yer alır. Doğa durumunda "herkesin saldırganı cezalandırmaya ve doğa yasasının uygulayıc1s1 olmaya hakk1 vardir" (Locke, 2014: 265). Ancak herkes adil olamayacaktır. Insanlar tarafgirdirler dolayısıyla kendilerini ve kendilerine yakın olanlara iltimas gösterirler. Insanlarda kötü huyluluk ve öç alma duygusu da baskındır. Bu olumsuz özellikleri sıralayarak insanların doğa durumundan çıkarak iktidarı oluşturduğunu ve insanların gönüllü onaylarıyla birlikte iktidarın meşruiyetinin sağlandığını söyler. Locke, Hobbes’un aksine, doğa durumunu olumsuz tasvir etmemiş ve iktidarın ortaya çıkışını kaos ya da güvenlik ihtiyacına dayandırmamıştır (Kuyurtar, 2014). Locke’a göre, insanların ortak irdeleriyle bir toplum sözleşmesi yaparak doğa durumundan çıkıp devleti oluşturmaları bireysel hak ve özgürlüklerini koruma isteğinden kaynaklıdır. Locke üzerine incelememiz sadece karşılaştırma amacıyla yapıldığı için detaylandırılamayacak olsa da Locke'un kuramında iktidarın ortaya çıkmasının doğal bir hak olarak görülen mülkiyetin güvenliği ile yakından ilişkili olduğunu belirtmek gereklidir.

Çalışmada toplum sözleşmecileri olarak adlandırılan grubun sonuncu üyesi olan J.J. Rousseau'nun insan doğasına bakış açısı La Boétie'nin bakış

\footnotetext{
11 Locke eşitlik ilkesini mutlak olarak tanımlamamaktadır. "Bir başkası üzerinde hakimiyet kurma ve yargilama açısından herkesin eşit hakka sahip olduğu bir durumdur. Özgürlügü yaratan budur: Kimseye bağlı ya da uyruk olmadan yaşayabilme" (Zabc1, 2009). Dolayisıyla eşit ve özgür olma bu anlamda birbirlerine sıkı bir şekilde bağlıdır.

12 Doğa yasası belirli bir zaman ve devlette var olan gelenek ve adetlerden farklıdır. Ayrıca pozitif hukuktan da bağımsızdır. İnsanlar arasındaki uzlaşmalarla koyulmuş kurallar ya da devletin uygulamadaki yasaları değildir. Doğa yasası normatif kuralları içerir. Bu sebeple evrenseldir.
} 
açısına benzemektedir. Rousseau da, Locke ve Hobbes gibi, insanların iktidar oluşturmadığ1 varsayımsal dönemi doğa durumu olarak tanımlar. Rousseau, Hobbes ve Locke'un doğa durumu tanımlamalarını eleştirirken, doğa durumundaki doğal insanla uygar insanın özelliklerini birbirine karıştırdıklarını ve uygar insana ait nitelikleri doğal insana yüklediklerini söyler. Ayrıca Hobbes ve Locke'un bilinçli veya bilinçsiz olarak doğa durumuna tarihsel gerçeklik yüklemelerini de eleştirir (Ağaoğulları, 2010: 35).

Rousseau doğal insanı toplumsal insana ait olan her şeyin yokluğuyla tanımlamıştır. Doğal insan eşit ve özgürdür. Bu insanı yönlendiren iki temel dürtü vardır: kendini sevme ve merhamet. Aklın dayanağı merhamet olarak tanımlanırken (Rousseau, 1995: 121), insanın kendisini sevmesi bencillik olarak adlandırılmıştır. Ancak bu bencillik Hobbes'un insanın temel dürtüsü olarak tanımladığı kendini koruma özelliğinden dolayı doğa durumunda tanımladığı gibi kaosu doğurmamaktadır. Çünkü kendisini seven bencil insan çatışmacı bir ilişkiye girmek yerine kendisini korumak içgüdüsü ile yalnızlaşmayı tercih eder. Merhamet ise hemcinslerin acı çekmesinden duyulan hoşnutsuzluktur. Merhamet duygusu insanların birbirine karşı saldırgan bir tavır içine girmelerini önler. Dolayısıyla doğa durumunda Hobbes'un tanımladığ gibi kaos ortamı yoktur. İnsan doğal olarak iyidir ancak bu iyiliğe ahlaki bir anlam yüklenmemektedir.

Rousseau Toplum Sözleşmesi eserine "insan özgür doğar, oysa her yerde zincire vurulmuştur" (Rousseau, 2015: 4) sözleriyle başlar. Rousseau insanların devleti kurma sürecini dört evrede açılamıştır. Özgür ve eşit olan toplumsallaşmamış doğal insan güçsüzlüğü nedeniyle hemcinsleri ile bir araya gelmeye mecbur kalır. Bu aşamada aile kuran ve iletişim yeteneklerini geliştiren insanlar işbölümü sürecini başlatarak aralarındaki ilk eşitsizliği de ortaya çıkarırlar. Doğal eşitsizlikler dışında eşit olan kadın ve erkek, işbölümü süreci ile eşitsiz konuma geçmiştir. İnsanların özgürlügünü ellerinden alan en önemli gelişme ise tarım ve madenciliğin keşfidir. Bu gelişme özel mülkiyetin doğması ve insanlar arasında çıkar çatışmasının başlamasıyla devam edecektir. Bu süreç insan doğasının bozulması ve bencilliğin merhametin yerini almasıyla Hobbes'un tanımladığı kaos sürecine doğru ilerleyecektir. Özel mülkiyet ile birlikte ortaya çıkan eşitsizlik belli kesimlerin diğerlerini köleleştirmelerine, onlara hakimiyet kurmalarına neden olacaktır. İşte devlet bu iktidar sahiplerinin koyduğu yasalar ile ortaya çıkacaktır. Rousseau bu durumu "yalancı sözleşme" olarak açılar (Kalfa \& Ataay, 2015). Devlet bu süreçle ortaya çıkmıştır. Rousseau, Hobbes'un doğa durumunda tanımladığı kaosa karşı çıkmıştır ancak devletin gerekliliğini savaşa bağlamasına hak vermiştir. Bu konuda Hobbes'u eleştirdiği nokta savaş durumunu doğa durumundaki insanlara yüklemesidir.

Machiavelli ve La Boétie'nin insan doğasına bakış açılarının karşılaştırmasını yaptıktan sonra toplum sözleşmecilerinin insan doğası ve 
iktidarın ortaya çıkışı düşüncelerini incelediğimizde düşünürlerin birbirlerine benzer ve birbirlerinden farklı fikirleri olduğu ortaya çıkmıştır. La Boétie'nin düşüncesinde olduğu gibi toplum sözleşmecilerinin düşüncelerinde de insanların iktidar kurulmadan önce özgür ve eşit olduğu düşüncesi hakimdir. Machiavelli haricinde incelediğimiz diğer düşünürler insanlar arasındaki eşitsizliği siyasal otoritenin kurulmasına bağlamışlardır. Locke ve Rousseau'nun insan doğasına ilişkin görüşleri La Boétie’nin ileri sürdüğü gibi olumlu özellikler sergilese de iktidarın ortaya çıkışının açıklanması için Machiavelli ve Hobbes'un insan doğasına bakış açılarına yöneldikleri görünmektedir. Toplum sözleşmecilerinin doğa durumunun bozulmasinın nedeni olarak sundukları en önemli etken ise mülkiyetin ortaya çıkmasıdır.

\section{4. İnsanlar Devlete Neden İtaat Eder?}

İnsanların iktidara neden itaat ettiği sorunsalı belki de insanlık tarihinde hiçbir zaman gerçek anlamda çözümlenemeyecektir. Düşünürlerce gerçekleştirilen insanın doğasını çözümleme tartışmaları, doğa durumu tasvirleri hem bu sorunun cevabını aramak hem de istenilen iktidar biçimine ulaşmak için araç olarak kullanılmıştır. Karşılaştırmasını yaptığımız düşünürler arasında doğa durumu tartsşması yapmayarak var olan durum üzerinden insan doğasını çözümleyerek ideal sistemine ulaşmaya çalışan tek düşünür Machiavelli'dir.

Machiavelli'ye göre insan doğası olumsuz özelliklerle dolu olduğu için insanlar ancak devletin hakimiyeti altında mutlu olacaklar ve bağımsız olan bu devlette toplumsal kurumlara uygun hareket ederek yaşadıklarında özgür olabileceklerdir. Buradan hareketle insanların iktidara itaat etmelerinin asıl gerekçesi içinde bulundukları toplumun refahının artması ve özgürlüğünün korunmasıdir.

Aristoteles, “insanın doğadan siyasal bir hayvan” (zoon politikon) (Aristoteles, 2006: 9) olduğunu söylese de, La Boétie ve toplum sözleşmecileri bu fikre katılmamaktadır. İnsanın doğasını kaybederek sonradan siyasallaştığını belirten La Boétie, siyasal yapıların insanın doğasına aykırı bir şekilde oluştuğu için kötülüğü bünyelerinde barındırdıklarını söyler. Peki, bu siyasallaşma durumu nasıl gerçekleşmiştir? La Boétie bunu bir kaza olarak adlandırır fakat bu kazanın nasıl gerçekleştiğine ilişkin bir bilgi vermez. Söylev'de verilen tarihsel örneklerden bu kazanın nasıl gerçekleşmiş olduğu konusunda çıkarım yapabileceğimiz üç yöntem sunmuştur. Bunlar, "kuvvet yolu”, "hile yolu” ve "üçüncü yol”dur (Ağaoğulları, 2008: 292).

Kuvvet yolu, bazı insanların zor kullanarak diğerleri üzerinde egemenlik kurmalarıdır. Hile yolu, halkın kurnazlık sonucu ya da kendi kendisini aldatarak tiran karşısında özgürlüğünü yitirmesidir. Üçüncü yol ise, halkın nedensiz bir şekilde kendisini boyunduruk altına sokan siyasal iktidarı yaratmasıdır. Bu evre siyasal toplumun "hükmetme-boyun eğme" ilişkisinin 
kurulduğu aşamayı açıklamak için anlamlıdır. Fakat siyasal iktidarın pekiştirilerek gönüllü kulluğun yaratılması için ikinci bir aşamaya ihtiyaç vardır ki o da "buyurma-onama" ilişkisidir (Ağaoğulları, 2008: 292-293).

Söylev'de halkın "boyun eğme" durumundan "onama" durumuna geçişinin, ekonomik çıkar, güvenlik, korkaklık ya da servet tutkusundan kaynaklanmadığını, asıl rolün iktidar tarafından oynandığını belirtilir. Gönüllü kulluğun iki nedeni vardır. Birincisini görenekler, alışkanlıklar ya da eğitimdir. Kültürel ve ideolojik yapılar vasitasıyla siyasi iktidar boyun eğme aşamasındaki insanlardan sonra gelen ikinci kuşağın üzerinde özellikle etkili olmaktadır. La Boétie’ye göre “illk başlarda, kuvvetle alt edilmişlikten dolayı zorlama nedeniyle hizmet edildiği bir gerçek. Fakat bundan sonra gelen kuşak, özgürlüğü hiç görmeyip tanımadığından dolayı, pişmanlık duymadan hizmet eder ve ondan öncekilerin zorla yaptıklarını seve seve yerine getirir"' (Boétie, 2014: 32). Bu kuşak özgürlüğü hiç tatmamış, tanımamıştır, tamamıyla kölelik içinde eğitilmiş ve doğal haklarından, doğalarından haberleri olmadığı için aldıkları eğitime göre yaşamlarına devam etmektedir. İkinci kuşağın durumunu Platon'un "Devlet" adlı eserinde kurguladığ1 "mağara mitosu"ndaki zincire bağlı insanların durumlarına benzetebiliriz. Platon mağara mitosunda, yeraltında mağaramsı bir yerde bulunan insanların çocukluklarından beri ayaklarından ve boyunlarından zincire vurulmuş olarak bu mağarada yaşadıklarını ve hareket edemediklerini söylemiştir. Bu insanların arka taraflarında yüksek bir yerde büyük bir ateş yanmaktadır. $\mathrm{Bu}$ ateş ile insanların arasında bir duvar vardır. Bağlı halde bulunan insanların tek gördükleri ve bildikleri şey bu duvarın üzerinde hareket eden şeylerin gölgeleridir. Bu tutsak insanlar için hayatın gerçeklikleri ancak gördükleri, gerçeğin yansıması olan gölgelerdir (Platon, 2007: 231-232). La Boétie'nin bahsettiği ikinci kuşak tam anlamıyla mağara mitosundaki insanlara benzemektedir. Doğa’larını bilmeyen ve siyasi iktidarın onlar için tanımladığı gerçeğin dışına çıkamayan insanlardır.

İkinci kuşak, siyasal iktidarı devirmeye yönelik herhangi bir eylemde bulunamaz. Çünkü bunu gerçekleştirebilmeleri için doğalarının özüne kavuşmaları, özgürlüğü tanımaları gerekmektedir. Oysa bu kuşak mevcut siyasi iktidarı sevip benimsemektedir. Sürdürdükleri yaşamdan farklı bir yaşam biçiminin olabileceğinin farkında değildir. La Boétie insanın iki farklı doğaya sahip olduğunu belirtir. İnsan iki ayrı doğaya sahip olan yegâne yaratıktır. Siyasi iktidarın oluşması sonucu, insanın birinci (gerçek) doğası yerini ikinci doğasına bırakır ve oluşan yeni insan kulluğu benimsemiştir (Gönen, 2013). Gönüllü kulluk ${ }^{13}$, "insanın boyun eğmeye rıza göstermekle kalmayıp, kulluğu sevip ona gönülden bağlanmasıdır" (Ağaoğulları, 2008: 296). Eğitimle, göreneklerle ve alışkanlıkların yaratılması sonucu oluşan bu

13 Göze bu durumu Türkçe’ye “iradi kölelik” olarak aktarmıştır (250). 
ikinci doğa birinci doğayı tamamen unutturacaktır. Bu aşama ile iktidar "hükmetme-boyun eğme" ilişkisine "buyurma-onama" ilişkisini ekler. İktidar tarafindan hegemonya ${ }^{14}$ kurulmuştur. Eğitim ve görenekler kullanılarak "zor"un yerine "rıza" konulmuştur.

La Boétie gönüllü kulluğun oluşma sürecini çözümlemeye başladığında ekonomik ç1kar, güvenlik, servet tutkusu gibi faktörlerin kulluk sürecinde etkisinin olmadığını savunmasına karşın iktidarın gönüllü kulluğu sürdürmek için sadece eğitim ve alışkanlıkları kullanmadığını belirtir. Kendisiyle çelişerek iktidar tarafından kullanılan diğer yöntemleri sayarken ekonomik çıkar ve servet edinme öğelerini de sıralamıştır. İktidarın kullandığı araçlardan ilki, halkın zevk ve eğlenceye alıştırılması ve boş şeylerle ilgilenmelerini sağlamaktır. "Tiyatrolar, oyunlar, eğlenceler, gösteriler, acayip hayvanlar, madalyonlar, tablolar ve diğer uyuşturucular eski halklar için kulluklaşmanın yemi, özgürlüğü yitirmenin bedeli, tiranlığın araçlarıdır” (Boétie, 2014: 43). Diğer yöntem ise, iktidarın halka belli maddi çıkarlar sağlayarak halkın algısı ile oynamak ve onun iktidara daha kuvvetli duygularla bağlanmasını sağlamaktır. La Boétie, "özgürlügüne yeniden kavuşmak amacıyla çorba tasını terk edemeyen halk"'1n (Boétie, 2014: 43) kendisine dağıtılanın aslında kendisinden fazlasıyla alınanın küçük bir kısmının geri dönüşü olduğunu fark edemediğini söyler. Halk kısa dönemli çıkarları uğruna, iktidara kulluğa devam etmekte ve sistemin devamını sağlamaktadır ${ }^{15}$.

İktidar ikinci kuşağın bilinçlenmesi ve kulluğunun farkına varamaması için cehaletin ve hurafelerin yaygınlaştırılmasına özen gösterir (A ğaoğulları, 2008: 299). Halkı uyandirabilecek aydınlar sinırlandırılır. Hurafelerle din adamlarının toplumdaki konumları etkinleştirilir. Din siyaset için kullanılırken en önemli sav iktidara tanrısallık yüklemektir. Bu yöntemlerle siyasi iktidar (tiran) kulluğu sadece fiziksel olarak değil, duygusal olarak da ele geçirmiş olur. Egemen devlet olarak merkezileşmek ve ortaya çıkmak için ise "hükmetmenin sırrının ve işleme aracının, tiranlığın desteğinin ve temelinin" (Boétie, 2014: 49) kurulması gerekmektedir. La Boétie burada Machiavelli'nin Prens eserinde bahsettiği var olan durumun çözümlenmesi ile iktidarın sürdürülebileceği ve etkinleştirilebileceği fikrine yakın bir sav ileri sürmüştür.

\footnotetext{
${ }^{14}$ Hegemonya, Antonio Gramsci'nin (1891-1937) yazılarında, "baskın toplumsal sınıfin zor kullanmak yerine egemenliği altındakilerin rızasını kazanarak iktidarını kullanma kabiliyetine işaret eder" (Heywood, 2015: 276; Sancar, 2005: 206).

${ }^{15}$ La Boétie'nin Antik Yunan okumalarının tam olduğunu düşünerek bu duruma Peisistratos dönemini örnek gösterebiliriz. Her ne kadar Peisistratos'u kesin olarak tiran şeklinde tanımlamasak da, döneminde uyguladığı politikalar Söylev adlı eserde verilen örneklere ciddi şekilde benzemektedir. Bu konuda daha detaylı bilgi için Yetiş’in makalesi incelenebilir (Yetiş, 1999).
} 
Hobbes insanların doğa durumundaki haklarından vazgeçerek iktidarı sözleşme ile oluşturmasını ve iktidara itaat etmesini güvenlik ihtiyacına (kaos halinden çıkmaya) bağlamıştır. Locke ve Rousseau böyle bir kaos durumundan bahsetmeseler de güvenlik gerekçesi onlar için de iktidarın korunması ve iktidara itaat için kullanılmıstır. Hobbes'un aksine La Boétie, Locke ve Rousseau doğa durumundaki durumu iktidarın oluştuğu topluma yeğ tutarlar. La Boétie Söylev'de açıkça iktidarın her türlüsünü reddetmesine karşın Barrere, Söylev'in "Prens" eserine karşı yazılmış örtülü bir cevap olabileceğini iddia etmiş, halk ve hükümdar arasında anayasal bir denge oluşturmak için yazılmış olabileceğini eklemiştir (Keohane, 1977: 121). İncelememizde La Boétie'nin Machiavelli'ye karşıt savlar sunduğunu tespit edebilmemize karşın, iktidarın anayasa ile sınırlandırılmasını savunan bir görüşüne rastlanmamıştır.

\section{Söylev'de Devletin Yapısı}

La Boétie Söylev’in ilk bölümlerinde gönüllü kulluğun failini halk olarak tanımlarken, yukarıda da açıkladığımız gibi kulluğun tek sorumlusunu halk olarak tanımlamamışır. Bu karşılıklı ilişkinin diğer tarafı tirandır. Ancak tiran bu sorumluluğu tek başına taşımaz, çünkü "Bir"in iktidarının ardında devlet mekanizması vardır. La Boétie'nin tirana yönelik eleştirileri kendisinden sonra egemenlik olarak tanımlanan modern devlete özgü gücün yansımalarıdır. La Boétie bu gücü egemenlik olarak tanımlamasa da bu gücün doğasından kaynaklı olarak tiranlığı içinde barındırdığını ortaya koyar. İktidara geliş nasıl olursa olsun (ister babadan oğula geçerek, ister halkın seçimi ile) iktidarın özünün tiranlığı barındırdığını söyler. La Boétie’nin çizdiği tiran sadece kaba güce dayalı ve korku imparatorluğu yaratan bir kişi değil, iktidarını halka benimsetmiş, meşruiyetini kazanmış ve toplumsal uzlaşıyı sağlamıştır. Halk bu sebeple gönüllü kulluğu benimseyip sürdürebilmektedir. Dolayısıyla metni derinden okuduğumuzda "tiran egemenden, tiranlık da kurumsallaşmış merkezi siyasal iktidardan başka bir şey değildir" (Ağaoğulları, 2008: 302).

Devlet ayg1tı Söylev'de bir sürü göze, ele, ayağa sahip tiran üzerinden açıklanmıştır. Tiran, "iki gözü, iki eli ve bir bedeni” (Boétie, 2014: 25) olan sıradan bir insandır, fakat halk ona kendi uzuvlarını bağışlamışıtır. Dolayısıyla tiranın halkın tamamını gözetleyen ve yöneten modern devlet aygıtını kurması sağlanmıştır. La Boétie bu sözlerle sanki Hobbes'un Leviathan'ını tarif etmiş, onun gücünü ortaya koymuş ve devletin doğası hakkında embriyonik bir teori sunmuştur (Keohane, 1977: 127; Sparling, 2013: 487489). Colosse $e^{16}$ benzetmesi ile siyasi iktidar1 elinde bulunduran tiran1 betimlerken, Colosse'yi ayakta tutanın onun kaidesi (temel) yani devlet örgütü

${ }^{16}$ Rodos'ta bulunduğuna inanılan Büyük Apollon heykeli. 
olduğunu vurgular. Burada iktidarın kaynağının halk olduğuna ilişkin yaptığı vurguya değinmek önemlidir. Halka verdiği öğütlerde tirana karş1 savaşmanın dahi gereksiz olduğunu, ona itaat edilmediğinde zaten kaidesinin ayaklarının altından kayacağını söylemiştir.

Machiavelli ile başlayan laik iktidar kurgusunun La Boétie'de de devam ettiğini görmekteyiz. Önemli olan diğer bir detay ise ikisinin de iktidarın kaynağını halkın rızasına dayandırmış olmasıdır. Fakat Machiavelli iktidarın prens tarafindan nasıl elde edilip sürekliliğinin nasıl sağlanacağına odaklanırken, La Boétie bireysel özgürlüğe odaklanmıştır (Boétie, 2008: 10).

La Boétie tiranın tek başına olmadı̆̆ını ve iktidarını sadece şiddete dayandırmadığını söyler.

"Tiranı koruyan atlı insan bölükleri, yaya insan sürüleri ya da silahlar değildir... Tirana destek olan ve tüm ülkeyi kulluk altında tutan hep dört ya da beş kişidir. Her zaman için beş ya da altı kişi tiranın gözüne girmiş gerek kendilerinden gelen istekle gerek tiranın çağırmasıyla ona yaklaşmış... Bu altı kişinin de çıkar sağladığı altı yüz kişisi vardır... Bu altı yüz kişi, buyruklarında altı bin kişiyi tutarlar... Bundan sonra gelenler çok daha fazla kalabalıktır" (Boétie, 2014: 52).

Karşı çıkılan durum sadece tiranlık değildir, aynı zamanda sistemin içerisinde bulundurduğu yozlaşmayı da net bir şekilde eleştirmiştir (Sparling, 2013: 486). La Boétie'nin betimlediği tiranın yönetimindeki devletin 20. ve 21. yy. totalitarizm ve kleptokrasilerinden (hırsılar yönetimi) farklı olmadığını görebiliriz. Ancak La Boétie’nin yaşamını sürdürmek için icra ettiği meslek düşünülünce kendisinin de bu yozlaşmanın bir parçası olduğu yorumunu yapmamız yanlış olmayacaktır.

Tiranın iktidarı kendi kabiliyetinden ya da halkın ondan korkmasından değil, sistemi yürüten devlet mekanizmasından kaynaklanır. Klientalist bir sistemle kurulan bu egemenlik biçimi toplumun tamaminı piramitsel bir biçimde kapsar (Göze, 1969: 252). Hiyerarşinin en üstündeki tiran, bu yap1 sayesinde halkın tamamını kontrol edebilmekte ve yönlendirebilmektedir. Ona göre yozlaşmanın en derin noktası insanların birbirlerini anlama, empati kurma özelliklerinin klientalist mantıkla aşındırılması ve toplumun atomize bireyler haline getirilmesidir (Sparling, 2013: 492).

Devleti oluşturan bu mekanizma ile kimisi "ateşli bir yükselme hırsılya" (Boétie, 2014: 53) kimisi ise "hatır1 sayllır bir para tutkusu" (Boétie, 2014: 53) ile tirana bağlanır, kendilerini tiran ile özdeşleştirerek, konumları ne olursa olsun bir başkasının efendisi olmayı arzularlar. "Büyük tiranın altında kendilerini küçük tiranlar yapabilmek için çevresinde toplanıp onu desteklemeye başlarlar” (Boétie, 2014: 53). Bu şekilde tiranlik toplumun tamamını kapsayan "toplumsal bir olgu” (Ağaoğulları, 2008: 304) şeklini alır. 
Sistem bu şekilde kurulduktan sonra tiranın iktidarını sürdürmek için herhangi bir faaliyette bulunmasına gerek kalmaz çünkü "tiran, uyruklarını birbirine kırdırarak kulluklaştırır” (Boétie, 2014: 54). Oluşturulan piramit biçimindeki yönetim ağ1 ile üst katmanlarda bulunanlar kendilerinden aşağıdakileri baskı altında tutabilmek için kulluğa razı olmaya devam ederler. Her kademenin bir küçük tiranlar grubu oluşmuş olur ve bu da düzenin sahiplenilmesini ve hükmetme ilişkilerinin yeniden üretilmesini sağlar. La Boétie burada tiran halk karşıtlığına küçük tiranları da eklemiştir.

La Boétie iktidar oluşturulduktan sonra tiranın bir şey yapmasına gerek kalmadığını vurgulamasına karşın, Machiavelli Prens eserinde bu duruma farklı bir yorum getirmiştir. Prense verdiği ögütlerde hayatın sürekli değişim içerisinde olduğunu ve bu değişim takip edilip yerinde kararlar verilmezse iktidarın sürdürülemeyeceğini vurgulamıştır. Machiavelli bu durumu bilimsel olarak çözümlemiştir. İnsanlık tarihini incelendiğimizde çok güçlü tiranların iktidarlarını devam ettiremediklerine şahit olmaktayız.

Söylev'de tirana daha yakın olanların kulluk seviyelerinin daha fazla olduğunu vurgulayan La Boétie halkın "ne kadar kulluklaştırılmış olursa olsun yalnızca kendine söyleneni yerine getirmekle yükümlü” (Boétie, 2014: 55) olduğunu, tirana yakın olanların ise tirana itaat etmelerinin yeterli olmayacağını onu hoşnut etmek zorunda olduklarını söyler. Tirana yakın olanlar (bürokrat, devlet görevlisi vb.) tiran tarafindan her an gözden çıarılabilecekleri gibi, halkın yaşadığı tüm sıkıntıların nedeninin ve nefret hislerinin tek odağ durumuna da düşerler. "Doğal olarak, halk katlandığ1 acıdan dolayı tiranı değil, fakat kendini yönetenleri suçlar... Tüm belalardan... ve her türlü kitliktan dolayı bunları sorumlu tutar...vahşi hayvanlara duyduklarından daha fazla tiksinme duyarlar" (Boétie, 2014: 61).

Devlet mekanizması bir kez kurulduktan sonra tekrar ortadan kalkmas1 mümkün görünmemektedir. Halk kendisini tiranın kişiliğiyle özdeşleştirmekte ve devlet sisteminin içerisinde kendisine yer bulmaya çalışmaktadır. Sisteme sadece itaat ederek, göreceli olarak dışında kalanlar ise devletin egemenliğine ya da tirana karşı bir eleştiri yöneltmemekte, tüm sorunların kaynağını kendilerini yöneten küçük tiranlarda aramaktadırlar. $\mathrm{Bu}$ sebeple La Boétie halkın tekrar doğa durumuna dönüp özgürlüğü elde etme ihtimalini görememiş ve tiranın cezasını Tanrı'ya bırakmıştır. La Boétie, kurumsallaşmış iktidarın kendisine karşı çıkmıştır, çünkü tiran öldüğünde yerine yeni bir tiran gelecektir (Keohane, 1977: 127). Tüm bu karamsar çizgiye rağmen La Boétie sistemin dişında kalan ve sistemi dağıtabilecek bir çıkış yolundan da bahsetmektedir.

\section{Gönüllü Kulluktan, Aydınlığa}

Söylev'in satır aralarında La Boétie yukarıda açıkladığımız kulluk sisteminden kurtulma yolları olduğunu belirtir. Kulluk bilinci, halkın özgür 
doğasını kaybetmesinden yani “özgür düşünme ve akıl yetisini” (Ağaoğulları, 2008: 307) kullanamamasından dolayı oluşmakta ve ortaya çıkmaktadır. Halk, iktidarın kurduğu hegemonya ile sistemin dişına çıkamamakta ve farklı bir yaşam biçimi olabileceğini düşünememektedir. Özgürlüğe kavuşmanın tek yolu gönüllü kulluk bilincinin ortadan kaldırılmasıdır. Ama bu nasıl ve kimler tarafindan gerçekleştirilecektir.

"Her dönemde diğer insanlardan daha iyi doğmuş bazı kişiler bulunur. Bunlar boyunduruğun ağırlığını hissedip sürekli ondan kurtulmaya çalışırlar ve bağımlılı̆̆a hiçbir zaman alışamazlar... Kendilerinden öncekilerin durumlarını düşünmeden edemezler... Kendiliğinden iyi bir kafa yapısına sahip olan bu kişiler, kafalarını eğitim ve bilgiyle daha da sağlamlaştırmışlardır. Bu kişiler, özgürlük yeryüzünde tümüyle yok olsa bile, özgürlüğü düşleyerek, hissederek ve hala onun tadını duyumsayarak kölelikten en ufak bir tat alamazlar” (Boétie, 2014: 38-39).

İşte sistemin bağını çözebilecek, gönüllü kulluktan sıyrılabilecek kişiler bu aydınlardır ve umut bu kişilere bağlanmıştır. Bilgiyle donanmış bu eğitimli kişilerin (aydınların) halkı özgürlüğü aramaya, özgürlüğünün peşinden koşma duygusuna sahip olmaya yöneltmeleri gerekmektedir ki, bu kolay bir iş değildir. Çünkü kulluk gönüllü olarak yapılmakta ve iktidar da bu durumu her daim yeniden üretmektedir. Sistem insanların aydınlanmasını engellemek için bireyleri sürekli denetim altında tutmaktadır. Sistem sadece kendi çıkarına hizmet eden bilgili insanların yaşamasına müsaade etmekte sistemin dışına çıkanların kendilerini ya da düşüncelerini ortadan kaldırmaktadır.

Söylev'in bir bölümünde La Boétie, tirana ve yöneticilere karş1 terörist eylemleri yüceltmiştir. "Erdemli bir biçimde ülkelerinin kurtulmasını tasarlayan Hermodius, Aristogiton, Thrasybules, yaşlı Brutus, Valerius ve (genç) Dionysos ${ }^{17}$ bunu başarıyla uygulamışlardı" (Boétie, 2014: 40). Burada bahsi geçen isimler ülkelerindeki tiranları deviren kişilerdir. Buradan da çıkarabileceğimiz gibi La Boétie, aydınlara özgürlük yolunda eylemde bulunmalarını, "ölmeyi ve öldürmeyi göze alarak" (Ağaoğulları, 2008: 309) halka sistemi sorgulatacak faaliyetlerde bulunmalarını önerir.

Söylev'in tutarsızlıklarından bir tanesi bu durumdur. Eserin başlangıcından itibaren tirana itaat etmemenin onun ortadan kalkması için yeterli olduğunu belirten La Boétie, eserin bu bölümünde eyleme geçme önerisi sunarak kendisiyle tekrar çelişmektedir.

\footnotetext{
${ }^{17}$ Hermodius ile Aristogiton, Atina tiranı Peisistratos'un oğlu tiran Hipparkhos'u öldüren kişilerdir. Thyrasybules İ.Ö. 409'da Atina'dan tiranlığı kovan kişidir. Yaşlı Brutus ile Valerius Publicola, tiran Tarqinius'u devirip Roma Cumhuriyetini kuranlardır. Genç Dionysos ise tiran yaşlı Dionysos'u devirip, daha sonra da Syraküza'da kendi tiranlğ̆ını kuran kişidir (Boétie, 2014: 40).
} 


\section{Sonuç Yerine}

La Boétie, insan doğasının özgür olduğunu eserinin tamamında vurgular ve insanların sonradan siyasallaştı̆ıını belirterek iktidarın sorgulanması sürecini başlatır. La Boétie, Locke ve Rousseau insan doğasına olumlu özellikler atfetmişler ve iktidarın oluşmasından önce bulunulan durumu (doğa durumu) idealleştirmişlerdir. Hobbes'un iktidarın kuruluşuna bakış açısı incelediğimiz diğer düşünürlerden farklı olsa da insan doğasını eşit ve özgür olarak kabul etmiştir. Leviathan eserinde insanlar arasinda yapilan sözleşme ile devleti oluşturarak insanların sonradan siyasallaştığı mesajını vermiştir. Ancak Hobbes, Machiavelli'nin çizgisinden ilerleyerek insan doğasına olumsuz özellikler yüklemiştir. Hobbes da Machiavelli gibi insanların iyiliğinin ve refahının merkezi otoritenin varllğıyla mümkün olabileceğini savunmuştur.

La Boétie, Söylev'de iktidarın ortaya çıkış sürecini üç madde ile tanımlamaya girişmiş, fakat bu olasılıkları incelemek yerine iktidarın varlığını nasıl sürdürdüğüne odaklanmıştır. İnsanların neden itaat ettiklerini başlangıçta onların özgürlük istencini kaybetmelerine bağlamış, ancak bu durumun tiranın faaliyetleriyle devam ettiğini saptayarak bu ilişkinin karşılıklı olduğunu vurgulamaya koyulmuştur.

Gramsci, hegemonya kavramını farklı koşullar ve yapısal durumlar için kullansa da, hegemonya kavramının La Boétie'nin bahsettiği buyurmaonama ilişkileri ile temelde yakın bağları vardır. Halkı suçlamaktan vazgeçmesini kulluğu kabul eden kuşaktan sonra gelen kuşağın özgürlüğü hiç tanımamasına bağlamıştır. Bu kuşak buyurma-onama aşamasının sorunsuz işlediği döneme karşllik gelmektedir. Louis Althusser'in İdeoloji ve Devletin İdeolojilk Aygutlar isimli çalışmasında aktardığı yöntemlerin birçoğunu La Boétie gönüllü kulluğun devam ettirilmesi sürecinde kullanılan araçlar olarak (din, kültür, gelenek vs.) tanımlamışır.

İnsanların iktidara itaat etmelerinin nasıl sağlandığını bu şekilde açıklayan La Boétie, "bir"'in yönetimi olarak aktardığı tiranın faaliyetlerine odaklandığında ise, tiran üzerinden devlet mekanizması tanımlar. Tiranın iktidarının kendi kişilik özelliklerine bağlı olmadığını, ona iktidarını sağlayanın ardındaki örgütlenmiş yapı olduğunu vurgular. Halka öğütlerinde sadece tirana itaat etmemelerinin onun ortadan kalması için yeterli olduğunu belirtmesine rağmen diğer taraftan tiranın sadece iktidarın görünen yüzü olduğunu ortaya koymuştur. Dolayisıyla tirana itaat etmeyi bırakan halk tiranın ortadan kalkmasını sağlasa dahi oluşan örgütlü yapı (küçük tiranlar) iktidarı korumaya devam edecektir. Tipkı iktidarın ortaya çıkışının sorumluluğunu önce insanlara yükleyip daha sonra tiranın faaliyetlerine odaklanarak tirana itaat edenleri özgürlüğü tanımayan kuşak olarak tanımlaması gibi, bu durum da La Boétie'nin Söylev'in başlangıcından itibaren savunduğu "kötülüğün, zorbalığın kaynağı iktidardır" söylemiyle 
çelişmektedir.

La Boétie'nin fikirleri farklı dönemlerde farklı ideolojilerin söylemlerine göre yorumlanarak çeşitli biçimlerde kullanılmıştır. İktidarı tamamıyla yadsıması onun anarşist olduğu yönünde fikirlerin ortaya atılmasına neden olmuştur. Heywood'un da belirttiği üzere, anarşizmin temel özelliği, devlete, devletin kurumları olan hükümet ve hukuka karşıtlığıdır. Anarşistler bask1 ve zorunluluğun olmadığ1, bireylerin özgür iradeleriyle ve gönüllü olarak işlerini yürüttügü devletsiz bir toplumu tercih ederler (Heywood, 2014: 192). Anarşistlerin, La Boétie'nin görüşlerine benzer bu tanımlamaları onun anarşist olarak yorumlanmasina neden olmuştur. "Hiçbir otoriteye inanmayan, insanların eşit ve özgür bireyler olabilmesi için kişileri baskı altında tutan bütün kurumların feshedilmesini savunan anarşizm" hiçbir otoriteyi kabul etmemektedir (Uğur, 2010: 139). Oysa La Boétie, “aile büyüklerimize itaatkâr olup aklın buyruğunda bulunacaktık” (Boétie, 2014: 27) diyerek ailenin otoritesini doğa durumunda dahi kabul etmiştir. Ayrıca eserinin sonunda da "tümüyle özgürlükçü ve yumuşak huylu olan Tanrı'ya, tiranlıktan daha aykırı bir şey olamaz" (Boétie, 2014: 62) yarg1sında bulunup tiranın cezasının Tanrı tarafından verileceğini söylemiştir. Görülüyor ki, La Boétie iktidarın kaynağını din olarak açıklamıyor olsa da, dini bir otorite olarak kabul etmektedir. Ocak Ferman Üzerine Inceleme adlı eserinde de, devletin içerisinde Katolik-Protestan ayrıllğının devleti ikiye böldüğünü söyleyerek, dinin devletin kontrolünde olması gerektiğini savunur. İktidarı kötülüğün kaynağ1 olarak sunmasına karşın, bu bildiride belirttiği Kilise iktidarının da monarşiye ait olduğu görüşü, Söylev eseriyle taban tabana zıttır. La Boétie'yi anarşist olarak tanımlamamız zordur, ancak metni anarşist bir metin olarak yorumlanabilir.

La Boétie'nin Söylev adlı eserinde tartıştığı, insanların neden iktidara boyun eğdikleri, iktidarların hakimiyetlerini nasıl korudukları gibi sorular günümüzde de tartışılmaya devam etmektedir. İktidara ilişkin yaptığ1 yorumlar ve sorduğu sorular modern siyasal teoride halen günceldir. Demokratik olmayan rejimlerin iktidara ilişkin faaliyetleri Söylev'de açıklanan hükmetme yöntemleriyle örtüşmektedir. La Boétie'nin tartıştığı bu konular iktidarın sınırlandırılması, insanların eşit ve özgür olduğu fikrinin yerleştirilmesi ve demokratik yönetimlerin kurulması yolunda atılan önemli adımlardan bir tanesidir. Erken bir kaynak olarak ortaya attığ1 fikirler toplum sözleşmecileriyle özellikle Locke ve Rousseau'nun toplum sözleşmeleriyle iktidarın kaynağının halk olduğu vurgusuyla pekiştirilmiş ve demokratik yönetimlere ulaşma süreci perçinlenmiştir. Ancak günümüzde özellikle Batı toplumlarında insanların siyasete ve iktidara ilişkin ilgileri azalmaktadır. Bu durumun nedenlerinden biri olarak ekonomik gelişme gösterilmektedir. Demokratik olarak adlandırılmalarına karşın bu ülkelerde iktidar süreçlerini La Boétie üzerinden incelemek farklı sonuçlar ortaya koyabilecektir. Bu incelemede La Boétie’nin vurguladığı iktidarın özünde kötülüğü barındırdığı 
fikri temelinde iktidara eleştirel yaklaşılması ve tiranın kullandığı araçların modern demokrasilerdeki karşılıklarının aranması, bu ülkelerdeki demokrasinin seviyesini de gözler önüne serecektir. 


\section{Kaynaklar}

Ağaoğulları, M. A. (2006). Kent Devletinden İmparatorlŭga. Ankara: İmge Kitabevi.

Ağaoğulları, M. A. (2011). Sokrates'ten Jakobenlere Bati'da Siyasal Düsünceler. İstanbul: İletișim Yayınları.

Ağaoğulları, M. A. (2008). Tanr Devletinden Kral-Devlete. Ankara: İmge Yayınlar1.

Ağaoğullar1, M. A. (2009). Thomas Hobbes: Ölümlü Tanr1. M. A. Ağaoğulları \& L. Köker (Ed.), Kral-Devlet ya da Ölümlï Tanr (ss. 163-281). Ankara: İmge Kitabevi.

Ağaoğulları, M. A. (2010). Ulus-Devlet ya da Halkın Egemenliği. Ankara: İmge Kitabevi.

Aristoteles. (2006). Politika. (M. Tunçay, Çev.) İstanbul: Remzi Yayınları.

Bağce, E. (2016). Okur-yazar.net. Okur-yazar.net: http://okuryazar.net/klientalizm-ya-da-yanasmacilik-2903 (Erişim tarihi: 25 Mart 2016).

Boetie, E. D. (2014). Gönïllï Kulluk Üzৃerine Söglev. (M. A. Ağaoğulları, Çev.) Ankara: İmge Yayınları.

Boetie, E. D. (2008). The Politics of Obedience: The Discourse of Voluntary Servitude. (H. Kurz, Çev.) Alabama: Ludvig von Mises Institute.

Coşkun, S. (2014). Jean-Jacques Rousseau. A. Tunçel \& K. Gülenç (Ed.), Siyaset Felsefesi Taribi Platon'dan Zizek'e (ss. 294-308). Ankara: Doğu Batı Yayınları.

García-Alonso, M. (2013). La Boétie and the Neo-Roman Conception of Freedom. History of European Ideas, 39 (3), 317-334.

Gönen, M. (2013). Çoğunluk, La Boetie ve Gönüllï Kulluk. Paradoks Film Dergi Sine Felsefe: http://www.paradoksdergi.com/index.php/sine-felsefe/80cogunluk-filmi-la-boetie-ve-gonullu-kulluk-metin-gonen-paradoksdergi (Erişim tarihi: 25 Mart 2016).

Göze, A. (1969). 16. Yüzy1l Düşünürlerinde Baskıya Karşı Direnme. İstanbul Universitesi Hukuk Fakültesi Mecmuasi, XXXV (1-4), 244-277.

Göze, A. (2016). Siyasal Düş̈nceler ve Yönetimler. İstanbul: Beta Basım Yayım.

Gülenç, K. (2014). Niccolò Machiavelli. A. Tunçel \& K. Gülenç (Ed.), Siyaset Felsefesi Taribi Platon'dan Zizeek'e (ss. 134-165). Ankara: Doğu Batı Yayınları. 
Heywood, A. (2015). Siyasetin Temel Kavramları. Ankara: Liberte Yayınları.

Heywood, A. (2014). Siyasi İdeolojiler. (Ö. Tüfekçi \& A. K. Bayram, Çev.) Ankara: Adres Yayınları.

Hobbes, T. (2014). Leviathan'dan Seçme Parçalar. M. Tunçay (Ed.), Bati'da Siyasal Düsünceler Taribi Yeni Çăg (ss. 209-253). İstanbul: İstanbul Bilgi Üniversitesi Yayınları.

Kalfa, C., \& Ataay, F. (2015). Rousseau ve Çoğunlukçu Demokrasi. Alternatif Politika, 7 (3), 457-489.

Keohane, N. O. (1977). The Radical Humanism of Étienne De La Boétie. Journal of the History of Ideas, 38 (1), 119-130.

Kulak, Ö. (2014). Thomas Hobbes. A. Tunçel \& K. Gülenç (Ed.), Siyaset Felsefesi Tarihi Platon'dan Zizek'e (ss. 217-236). Ankara: Doğu Bat1 Yayınları.

Kurz, H. (1946). Did Montaigne Alter La “Boétie's Contr'un?" Studies in Philology, 43 (4), 619-627.

Kurz, H. (1949). The Actuality of Etienne de la Boétie. World Literature Today, 23 (2), 127-128.

Kuyurtar, E. (2014). John Locke. A. Tunçel \& K. Gülenç (Ed.), Siyaset Felsefesi Tarihi Platon'dan Zizek'e (ss. 249-263). Ankara: Doğu Bat1 Yayinları.

Locke, J. (2014). Uygar Yönetim Üzerine İkinci İnceleme. M. Tunçay (Ed.), Bati'da Siyasal Düsünceler Taribi Yeni Căg (ss. 261-294). İstanbul: İstanbul Bilgi Üniversitesi Yayınları.

Machiavelli, N. (2015). Prens. (K. Atakay, Çev.). İstanbul: Can Sanat Yayınlar1.

Moore, B. J. (2012). Diktatörlüğ̈̈n ve Demokrasinin Toplumsal Kökenleri Căğdas Dünyanm Yaratılmasında Soylunun ve Köylünün Rolü. (Ș. Tekeli \& A. Şenel, Çev.). Ankara: İmge Kitabevi.

Newman, S. (2010). Voluntary Servitude Reconsidered:Radical Politics and the Problem of Self-Domination. Anarchist Devolopments in Culturel Studies, 31-49.

Pieters, J., \& Roose, A. (2006). The Art of Saying 'No'. Premonitions of Foucault's 'Governmentality' in Étienne de La Boétie's Discours de la servitude volontaire. J. Deploige \& G. Deneckere (Ed.), Mystiffing the Monarch: Studies on Discourse, Power and History (79-97). Amsterdam: Amsterdam University Press. 
Platon. (2007). Devlet. (S. Eyüboğlu, \& M. A. Cimcoz, Çev.) İstanbul: Türkiye İş Bankası Yayınları.

Price, R. (2012). Fransa'nın Kısa Taribi. (Ö. Akpınar, Çev.) İstanbul: Boğaziçi Üniversitesi Yayınları.

Rousseau, J. J. (1995). Insanlar Arasındaki Eşitsizlĭğn Kaynă̆ı. (R. N. İleri, Çev.). İstanbul: Say Yayınları.

Rousseau, J. J. (2015). Toplum Sözleşmesi. (V. Günyol, Çev.) İstanbul: Türkiye İş Bankası Yayınları.

Sancar, S. (2005). Hegemonya. F. Başkaya içinde, Kavram Sözlügü Söylem ve Gerçek (205-211). Ankara: Maki Basın Yayın.

Schaefer, D. L. (2013). Discourse on Voluntary Servitude by La Boétie. Chicago: The University of Chicago Press on behalf of the Renaissance Society of America.

Sparling, R. (2013). Sunlight is the best disinfectant? Étienne de la Boétie on corruption and transparency. European Journal of Political Theory, 12 (4), 483-509.

Uğur, G. (2010). Dünden Bugüne Anarşizm ve Anarşizmin Çözmesi Gereken Sorunlar. Gazi Üniversitesi İIBF Dergisi 12 (1), 133-158.

Yetiş, M. (1999). Antik Atina'da Demokrasinin Gelişimi: Soloncu Pasif Devrimden Peisistratos'un Tiranlığına. Ankara Üniversitesi SBF Dergisi, 54 (2), 160-195.

Zabc1, F. (2009). John Locke: Liberalizmin Düşüncedeki Öncüsü. M. A. Ağaoğulları, F. Zabc1, \& R. Ergün (Ed.), Kral-Devletten Ulus-Devlete (ss. 101-232). Ankara: İmge Kitabevi.

Zweig, S. (2012). Montaigne. (A. Cemal, Çev.) İstanbul: Can Yayınları. 